\title{
Endemic and emerging arboviruses of mosquitoes in Ecuador
}

\author{
Rachel Sippy[1], Cat Lippi[2], Anna Stewart Ibarra[1], Sadie Ryan[2] \\ 1. SUNY-Upstate Medical University, Syracuse, United States of America \\ 2. Independient investigator, United States of America
}

Doi: https://doi.org/10.23936/pfr.v5i2.165

PRÁCTICA FAMILIAR RURAL | Vol.5 | No.2 | Julio 2020 | Received: 03/26/2020 | Approved:12/07/2020
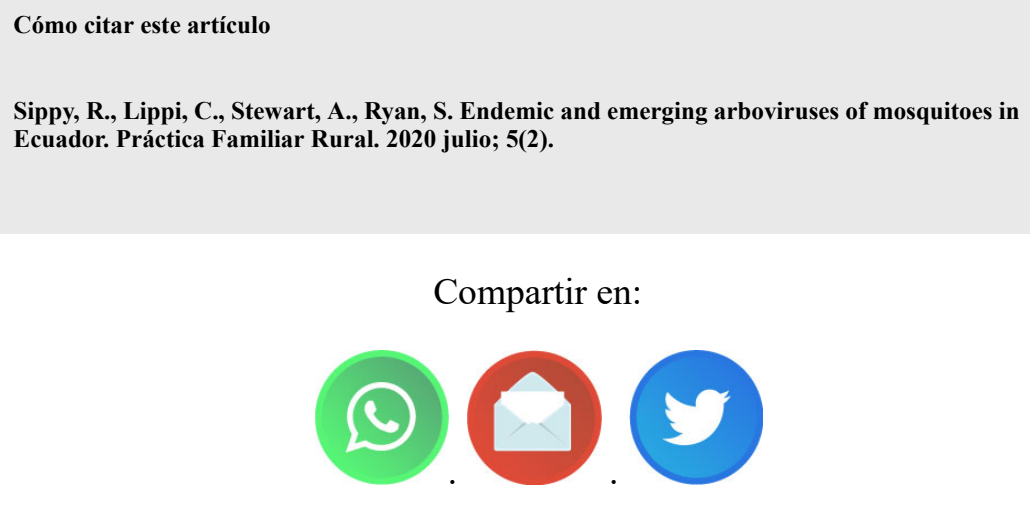

\begin{abstract}
Arboviruses are arthropod-borne viruses that include many viruses of public health concern found in Ecuador. Dengue virus, yellow fever virus and Zika virus are in the Flaviridae family (1), while chikungunya virus and Mayaro virus are in the Togaviridae family (1). Yellow fever has circulated throughout the tropics since at least the17th century, with the first recorded outbreak in Latin America in 1647 (2), with the virus being identified in 1927 (3). Dengue virus is also a long-time source of global outbreaks and was identified in 1943 (4). Dengue has four virus serotypes (DENV 1-4), allowing for repeated infection of individuals. Chikungunya, Zika and Mayaro were identified as causes of febrile disease more recently: the Zika virus was isolated from a monkey in 1947 in Uganda (5), chikungunya virus during an outbreak in south-eastern Africa in 1952 (1), and Mayaro virus from a patient in Trinidad in 1954 (6). Chikungunya has four genotypes: East/Central/South African, Western African, Indian Ocean and Asian (1), while Zika has two genetics lineages: Asian and African (7). Ecuador is susceptible to introductions of arboviruses transmitted by several mosquito vectors that are either well established or recently introduced and has thus experienced multiple and repeated introductions of these diseases. Of these, at present, only yellow fever has a widely available and licensed vaccine.
\end{abstract}

Keywords: arbovirus, endemic, pandemic, tropical medicine.

\section{Arbovirosis endemicas y epidemicas en Ecuador}

\section{Resumen}

Los arbovirus son virus transmitidos por artrópodos que incluyen muchos virus de preocupación para la salud pública que se encuentran en Ecuador. El virus del dengue, el virus de la fiebre amarilla y el virus Zika están en la familia Flaviridae (1), mientras que el virus chikungunya y el virus Mayaro están en la familia Togaviridae (1). La fiebre amarilla ha circulado por los trópicos desde al menos el siglo XVII, con el primer brote registrado en América Latina en 1647 (2), y el virus se identificó en 1927 (3). El virus del dengue es también una fuente de brotes globales desde hace mucho tiempo y se identificó en 1943 (4). El dengue tiene 
cuatro serotipos de virus (DENV 1-4), lo que permite la infección repetida de individuos. Chikungunya, Zika y Mayaro se identificaron como causas de enfermedad febril más recientemente: el virus Zika se aisló de un mono en 1947 en Uganda (5), el virus chikungunya durante un brote en el sudeste de África en 1952 (1) y el virus Mayaro de un paciente en Trinidad en 1954 (6). Chikungunya tiene cuatro genotipos: este / centro / sur de África, África occidental, Océano Índico y asiático (1), mientras que Zika tiene dos linajes genéticos: asiático y africano (7). Ecuador es susceptible a la introducción de arbovirus transmitidos por varios mosquitos vectores bien establecidos o recientemente introducidos y, por lo tanto, ha experimentado múltiples y repetidas introducciones de estas enfermedades. De estos, en la actualidad, solo la fiebre amarilla tiene una vacuna ampliamente disponible y autorizada.

Palabras clave: arbovirus, endemia, pandemia, medicina tropical.

\section{Background}

Arboviruses are arthropod-borne viruses that include many viruses of public health concern found in Ecuador. Dengue virus, yellow fever virus and Zika virus are in the Flaviridae family (1), while chikungunya virus and Mayaro virus are in the Togaviridae family (1). Yellow fever has circulated throughout the tropics since at least the 17th century, with the first recorded outbreak in Latin America in 1647 (2), with the virus being identified in 1927 (3). Dengue virus is also a longtime source of global outbreaks and was identified in 1943 (4). Dengue has four virus serotypes (DENV 1-4), allowing for repeated infection of individuals. Chikungunya, Zika and Mayaro were identified as causes of febrile disease more recently: the Zika virus was isolated from a monkey in 1947 in Uganda (5), chikungunya virus during an outbreak in south-eastern Africa in 1952 (1), and Mayaro virus from a patient in Trinidad in 1954 (6). Chikungunya has four genotypes: East/Central/South African, Western African, Indian Ocean and Asian (1), while Zika has two genetics lineages: Asian and African (7). Ecuador is susceptible to introductions of arboviruses transmitted by several mosquito vectors that are either well established or recently introduced and has thus experienced multiple and repeated introductions of these diseases. Of these, at present, only yellow fever has a widely available and licensed vaccine.

\section{Vectors}

Several species of mosquitoes spread the arboviruses described here. Some of the mosquito species are primary or secondary vectors (the main sources of transmission to humans), while other species are infected with the viruses in the wild and may only rarely transmit the virus to humans; the potential transmission cycles of these viruses are described in Box. Aedes aegypti is a primary vector for yellow fever, dengue, chikungunya, and Zika viruses (8). Aedes albopictus is an important vector for these arboviruses in many parts of the world, sometimes as the primary but more often as the secondary vector. It was detected in Guayaquil in 2017 (9) but is not believed to be widely distributed nor playing as important a role in arboviral transmission in Ecuador. Both Ae. aegypti and Ae. albopictus are expected to expand their range due to climate change (10), and this is anticipated to impact Ecuador. Haemogogus spp is the suspected vector of Mayaro virus (6), and is a known vector of yellow fever; for yellow fever these mosquitoes maintain sylvatic viral reservoirs but are not important sources of human disease (3).

\section{BOX: Sylvatic and Urban Transmission Cycles}

Pathogens transmitted by mosquitoes can spread through sylvatic or urban transmission cycles. The same pathogen can spread through both transmission cycles, depending on location and circumstances. In the urban transmission cycle, humans are the main or only mammalian host, and a disease persists via biting and transmitting by anthropophilic mosquito vectors. This is well represented by dengue fever, transmitted by Aedes aegypti mosquitoes, which are container-breeding urban vectors, well adapted to peri-domicilary habitats. This is also the form of yellow fever outbreaks that occur in urban settings, when yellow fever virus is circulated primarily between people and Aedes aegypti mosquitoes in the urban environment, without any sylvatic involvement.

Sylvatic transmission refers to the cycle of pathogen transmission between sylvatic hosts. Sylvatic means 'of the forest', so this is commonly a wildlife and sylvatic vector cycle. In the Americas, yellow fever is thought to persist in a sylvatic cycle, between non-human primates and forest-dwelling mosquito vectors.

The introduction of sylvatic cycling pathogens into human populations occurs in two forms: 
1. Dead-end: Humans may interact with the sylvatic cycle, getting bitten by a sylvatic vector, becoming infected and exhibiting disease symptoms, but either not generating sufficient pathogen load to spread to an anthropophilic vector, or simply not encountering a vector that is competent to transmit the pathogen onward. In this case, the human is known as a 'dead-end host' and the cycle does not continue. This is the case for human cases of Eastern equine encephalitis virus and West Nile virus, in which people are bitten by 'bridge' vectors - mosquitoes that will bite sylvatic animals, such as birds, reptiles, and other mammals, and also humans.

2. Sylvatic-urban emergence: In some cases, a human is infected after interacting with the sylvatic cycle and has high enough pathogen load (viral titer) to infect an anthropophilic mosquito, which can then infect another human. This can spark an urban cycle, as is the case with some urban yellow fever outbreaks. In the African yellow fever cycle, there are mosquito species that are competent anthropophilic bridge vectors, which persist in rural environments, maintaining a middle piece of the sylvatic-urban emergence boundary. In the Americas, it is thought that there are fewer of these in-between vector bridges, but this may simply be a gap in knowledge.

Table 1: Viruses and Vectors

\begin{tabular}{|c|c|c|c|c|c|}
\hline Virus & Type & Family & Transmission & Known Vectors & Source(s) \\
\hline Chikungunya & RNA & Togaviridae & $\begin{array}{l}\text { Mosquito bite, } \\
\text { maternal-fetal, } \\
\text { perinatal (rare) }\end{array}$ & $\begin{array}{l}\text { Aedes aegypti } \\
\text { Aedes albopictus }\end{array}$ & (11) \\
\hline Dengue & RNA & Flaviviridae & Mosquito bite & $\begin{array}{l}\text { Aedes aegypti } \\
\text { Aedes albopictus }\end{array}$ & (12) \\
\hline Mayaro & RNA & Togaviridae & Mosquito bite & $\begin{array}{l}\text { Haemagogus } \\
\text { spp. Aedes spp. } \\
\text { Culex spp. } \\
\text { Mansonia spp. } \\
\text { Psorophora spp. } \\
\text { Sabethes spp. }\end{array}$ & $(6,13)$ \\
\hline Yellow fever & RNA & Flaviviridae & Mosquito bite & $\begin{array}{l}\text { Aedes aegypti } \\
\text { Aedes albopictus } \\
\text { Haemogogus } \\
\text { spp. } \\
\text { Sabethes spp. }\end{array}$ & (3) \\
\hline Zika & RNA & Flaviviridae & $\begin{array}{l}\text { Mosquito bite, } \\
\text { sexual, perinatal }\end{array}$ & $\begin{array}{l}\text { Aedes aegypti } \\
\text { Aedes albopictus } \\
\text { Aedes spp. }\end{array}$ & (14) \\
\hline
\end{tabular}

MTC=mother to child, RNA=ribonucleic acid, spp=species

\section{Clinical disease, immunology, and diagnostic testing}

Clinically, the illnesses caused by Aedes-borne arboviruses can be difficult to distinguish, as they largely present as febrile illness, when symptomatic. Additionally, these infections have a variety of presentations with few distinguishing characteristics, with some proportion of infected individuals experiencing no symptoms (Table 2). Yellow fever confers lifelong immunity and has a safe and effective vaccine available (3). Individuals can be infected with dengue more than once, due to incomplete protection from antibodies across different dengue serotypes (15); secondary infection with a new dengue serotype can lead to more severe symptoms and increased risk for dengue hemorrhagic fever (15). Although a vaccine for dengue fever had been developed its implementation was undermined by safety concerns, where the vaccine increased the risk of severe disease in people without a history of prior dengue infection (16). Chikungunya can only infect patients once (antibodies confer lifelong immunity) (8). It is believed that the immunity for Zika is also lifelong (8). Co-infection with multiple viruses is possible and has been reported in Ecuador (17), but it is unknown how the presence of multiple viruses affects clinical presentation of disease. Table 2 summarizes the typical and severe presentation of symptoms for each disease. In Ecuador, several diagnostic tools are available to distinguish these infections: rapid tests, serological tests (IgG and/or IgM enzyme linked immunosorbent serological assays (ELISA)), and molecular tests (polymerase chain reaction (PCR)). For chikungunya, ELISAs are used in MSP clinics and are available in many clinical laboratories. For dengue, a rapid test is available, to test for the presence of viral proteins in serum (NS1 
rapid test) (18). IgG and IgM ELISAs can also be used to confirm dengue and determine if the infection is primary or secondary and is used by both INSPI (18) and some clinical laboratories. Quantitative PCR is also used by INSPI to test some cases (18). There are no approved clinical diagnostic tests available to confirm Mayaro infection in Ecuador, but samples can be tested by INSPI (19). For yellow fever, either PCR or ELISA is used depending on the date of symptom onset. For Zika infection, ELISAs are used in MSP clinics and are available in many clinical laboratories.

Table 2: Clinical Presentation of Select Arboviruses

\begin{tabular}{|c|c|c|c|c|c|c|c|}
\hline Virus & \begin{tabular}{|c|} 
Disease(s) or \\
Complications
\end{tabular} & \begin{tabular}{|c|} 
Typical \\
Duration \\
of Acute \\
Illness
\end{tabular} & $\begin{array}{c}\text { Percent } \\
\text { Asymptomatic }\end{array}$ & $\begin{array}{l}\text { Percent } \\
\text { Severe }\end{array}$ & $\begin{array}{l}\text { Typical } \\
\text { Symptoms }\end{array}$ & Severe Symptoms & Source(s) \\
\hline Chikungunya & $\begin{array}{l}\text { Chikungunya } \\
\text { infection, } \\
\text { chikungunya } \\
\text { arthritis, } \\
\text { Guillain-Barré } \\
\text { syndrome }\end{array}$ & 7-10 days & $5-28 \%$ & $14-87 \%$ & $\begin{array}{l}\text { Fever, pain (joint } \\
\text { or muscle), joint } \\
\text { swelling, } \\
\text { headache, rash, } \\
\text { conjunctivitis }\end{array}$ & $\begin{array}{l}\text { Relapsing } \\
\text { symptoms }\end{array}$ & $(11,20)$ \\
\hline Dengue & $\begin{array}{l}\text { Dengue fever, } \\
\text { dengue } \\
\text { hemorrhagic } \\
\text { fever, dengue } \\
\text { shock } \\
\text { syndrome }\end{array}$ & 2-7 days & $50-75 \%$ & $-5 \%$ & $\begin{array}{l}\text { Fever, } \\
\text { nausea/vomiting, } \\
\text { rash, pain (retro- } \\
\text { orbital, muscle, } \\
\text { joint, or bone) }\end{array}$ & 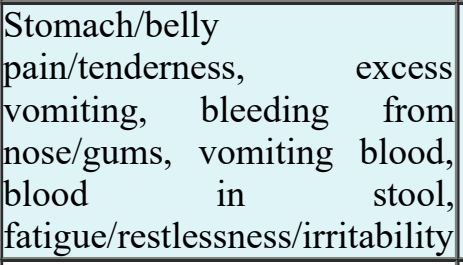 & $(12,21)$ \\
\hline Mayaro & $\begin{array}{l}\text { Mayaro } \\
\text { infection }\end{array}$ & 3-10 days & unk & $>50 \%$ & $\begin{array}{l}\text { Fever, malaise, } \\
\text { headache, pain } \\
\text { (muscle, joint, or } \\
\text { retro-orbital) }\end{array}$ & $\begin{array}{l}\text { Long-term rheumatologic } \\
\text { symptoms }\end{array}$ & $(6,22)$ \\
\hline Yellow fever & Yellow fever & 3 days & $87-93 \%$ & $15-20 \%$ & $\begin{array}{l}\text { Fever, chills, } \\
\text { headache, pain } \\
\text { (back, } \\
\text { generalized), } \\
\text { nausea/vomiting, } \\
\text { fatigue, } \\
\text { weakness } \\
\end{array}$ & $\begin{array}{lrr}\text { High } & \text { fever, } & \text { jaundice, } \\
\text { bleeding, } & \text { shock, organ failure }\end{array}$ & $(3,23,24)$ \\
\hline Zika & \begin{tabular}{|l|} 
Zika infection, \\
Guillain- Barré \\
syndrome, \\
microcephaly \\
(fetal), \\
congenital \\
Zika syndrome \\
(fetal)
\end{tabular} & 2 weeks & $80 \%$ & rare & \begin{tabular}{|lr} 
Fever, & rash, \\
headache, & pain \\
(joint & or \\
muscle), & \\
conjunctivitis
\end{tabular} & $\begin{array}{l}\text { Microcephaly or other birth } \\
\text { defects }\end{array}$ & $(12,14,25)$ \\
\hline
\end{tabular}

\section{Epidemiology}

All of these viruses are part of the Ecuador MSP Subsistema de Vigilancia de Enfemedades Transmitidas por Vectores. Today, dengue remains a constant threat to health in Ecuador, particularly in coastal regions, while chikungunya, yellow fever, and Zika have receded from surveillance reports. In 2019, 2 cases of chikungunya were reported in Ecuador (26); no cases have been reported in 2020 as of epidemiological week (EW) 14 (27). Dengue infections were reported in 8,416 people in 2019, with Orellana, Esmeraldas, and Zamora Chinchipe experiencing the highest infection rates (26). 2020 has had a high burden of dengue cases so far, with 6,941 cases reported in the first 14 EW (27). Mayaro infections first appeared in Ecuador in 2019, with 5 cases reported in coastal Ecuador. Yellow fever cases were last reported in Ecuador in 2017 (3 cases) and Zika in 2018 (10 cases) (27). It is unknown if these viruses are still circulating in vector populations, in sylvatic cycles, or through asymptomatic infections in human populations.

\section{History of mosquito-borne arboviruses in Ecuador}

Historically, Ecuador was plagued by yellow fever and malaria outbreaks (2), with combined efforts to control these diseases beginning in Guayaquil in 1906 (28). Yellow fever outbreaks were eliminated in 1920 (28), but the maintenance of sylvatic reservoirs in the Amazon region allowed outbreaks to recur (29). The Sistema Nacional de Eradicación de 
Malaria (SNEM) was founded in 1956 and worked to control multiple vector-borne diseases, including yellow fever (28). Aggressive vector control efforts led to the eradication of Ae. aegypti from Ecuador in 1951 and near-eradication of $A e$. aegypti from South America in the 1960's, but control program cutbacks allowed the species to proliferate and return to Ecuador (24) in the 1970's. Large outbreaks followed in the 1980's and 1990's, leading to vaccination campaigns using the yellow fever vaccine developed in the 1930's (24). Ecuador added the yellow fever vaccine to the childhood vaccination schedule in 2000 , contributing to the decline of this disease.

Dengue was likely present in Ecuador before the 20th century, causing periodic outbreaks thought to be caused by a single serotype (29). Efforts to eradicate Aedes aegypti to control yellow fever also led elimination of dengue fever for the 1960's and 1970's (29). Reemergence of dengue in Ecuador began in 1988 with DENV-1 (18). By 2000, all four dengue serotypes were in Ecuador $(15,18)$, causing a large outbreak $(22,937$ cases) in that year (4). The co-circulation of these serotypes contributes to a pattern of strong dengue outbreaks every 3-5 years (30). In a single year, all four serotypes may be present with one serotype often dominating (18). The most recent available analyses by INSPI found that serotypes 1 and 2 were circulating in 2019 (26).

Chikungunya was introduced to the Caribbean in 2013 and caused a major epidemic in nearly 50 countries, including Ecuador, beginning in late 2015 (12), though clinical descriptions from a series of outbreaks in Central America and the Caribbean in the 1820's suggest chikungunya has been to the Americas before (4). Although there are multiple strains of chikungunya, the Asian strain is responsible for the large outbreak in the Americas, though the East/Central/South African was also detected in Brazil (1). Zika followed shortly after, arriving to the Americas in May 2015 (14), with the first case reported in Ecuador in January 2016.

There are several arboviruses that could potentially cause widespread public health problems in Ecuador due to the presence of suitable mosquito vectors. Mayaro was reported in Ecuador after INSPI decided to screen patients who were otherwise negative for dengue, chikungunya, and Zika, finding 5 positives (19). Other serological research has identified high Mayaro seroprevalence (46\%) among Ecuadoreans from Amazonian provinces (13). Due to its relatively mild symptoms, it may continue to circulate silently in Ecuador, or could potentially cause outbreaks as it has in Venezuela (31). Venezuelan equine encephalitis (VEE) is caused by an Alphavirus spread through many mosquito species that feed on mammals, including Culex spp. and Aedes spp. This is another example of a potentially emerging vector-borne disease in Latin America, where VEE outbreaks have been reported in humans and horses (32). An outbreak of VEE occurred in Ecuador in 1969, part of a larger regional outbreak (33), and testing among subjects with undifferentiated febrile illness yielded a VEE-positive result (34). Oropouche virus, a zoonotic Orthobunyavirus spread by Aedes serratus, Coquillettidia venezuelensis, and Culex quinquefasciatus mosquitoes and Culicoides midgeshas caused outbreaks in Brazil, Panama, Peru and Trinidad and Tobago (35). The mosquitoes and reservoirs that comprise the Oropouche transmission cycle are also present in Ecuador, and there is a report of one human case from Ecuador's Amazon region (34), meaning Oropouche fever outbreaks could occur if the virus escapes its sylvatic cycle. Another potential threat is Usutu virus: this Flavivirus is also spread by Culex spp. This virus has caused frequent outbreaks in Europe and the high rate of travel between Ecuador and Europe (and the presence of Culex spp. in Ecuador) could potentially lead to its introduction to Ecuador (31). There is great diversity in arboviral pathogens and their vectors, and therefore the potential for novel and emerging mosquito-borne diseases in Ecuador is not limited to those discussed here.

\section{Mosquito-borne Arboviral Disease Research in Ecuador}

Descriptive studies of mosquito-borne arboviruses in Ecuador include clinical reports, serological surveys, or entomological surveys. Clinical reports have demonstrated the complexity of arboviral disease presentation among patients in Ecuador, including coinfections and complications (36). Studies of undifferentiated febrile illness or serological surveys have provided important insights into infections that are potentially missed by the current surveillance system in Ecuador, including Mayaro disease (13,34,37). Entomological surveys show the suitability of Ecuadorian habitats for many mosquito species and detection of new species to Ecuador $(9,38,39)$, and demonstrated that Asian lineages of chikungunya and Zika were circulating in Ae. aegypti populations in Ecuador (7).

Research efforts have revealed important information about mosquito populations and their habitats in Ecuador, including the impact of altitude and environment on presence of Ae. and Culex species $(39,40)$, habitats of Ae. aegypti and the climate or environmental factors that influence Ae. aegypti abundance (41-44), the genetic complexity, adaptation, and vectoral capacity of Ae. taeniorhynchus populations in Galápagos (45-49), and the preferred hosts of Ae. taeniorhynchus and Culex quinquefasciatus $(46,50)$.

Several studies have examined vector control by the public health sector in Ecuador. Surveys with mosquito control programs and among households detail the typical vector control efforts from municipal services $(42,51)$, including home visits to inspect water tanks, conduct indoor residual spraying, and provide larvicides, as well as municipal fumigation and other insecticide applications. However, field studies and laboratory experiments show the impact of widespread insecticide use and demonstrate the need for new vector control strategies due to the development of resistance (52) and 
the importance of targeted efforts for high-risk homes (44) and efficient delivery of vector control services (53). Experimental studies in Ecuador are testing the potential for new mosquito control devices (54).

Prospective active surveillance studies of arboviral infections in southern coastal Ecuador have generated high-resolution longitudinal epidemiological datasets and sample banks (18). These studies have elucidated the burden of arboviral disease and clinical presentation across demographic groups, the DENV serotypes and strains in circulation, the prevalence of primary versus secondary dengue infections, and the ratio of symptomatic to subclinical infections. Researchers found that the burden of symptomatic DENV infections was greatest in children aged less than 10 years, whereas adults greater than 60 years of age bore the greatest burden of symptomatic CHIKV infections. During the first CHIKV epidemic in 2015, this study found a high proportion of CHIKV infections that were misdiagnosed as dengue and the high prevalence of DENV and CHIKV co-infections. Forty-three percent of clinically diagnosed (suspected) DENV cases were positive for CHIKV (and negative for DENV); $11.5 \%$ of subjects with CHIKV infections were also positive for DENV. During the CHIKV epidemic, researchers documented a peripartum case with DENV and CHIKV coinfections, with a benign clinical course and favorable pregnancy outcome (36). In this same population, investigators explored the role of micronutrients in arboviral disease, and found that serum ferritin and retinol-binding protein concentrations (nutritional biomarkers) were associated with symptomatic dengue infections (55).

Other studies have documented co-infections of arboviruses with non-arboviral vector borne diseases (tick borne disease and Chagas disease) in this same population. A recent study found that $25 \%$ of individuals with dengue-like febrile illness had evidence of anti-spotted fever group rickettsial antibodies, and co-infections with DENV and CHIKV were detected (56). This was the first report of tickborne illness and arbovirus co-infections from this region. Mita-Mendoza et al. documented a low prevalence of Chagas disease in this region $(0.91 \%)$, caused by the Trypanosoma cruzi parasite, and identified one case of T. cruz/dengue co-infection and one case of $T$. cruzi/chikungunya/dengue coinfection (57).

Three studies of note have compared arbovirus and vector dynamics from Ecuador to other regions of the world. Quintero et al. compared field data from household mosquito pupal surveys conducted in cities in Ecuador (Machala), Mexico, Colombia, Brazil and Uruguay (42). The authors found that Ecuador had the highest Ae. aegypti pupal indices amongst the five countries, suggesting an elevated risk of arboviral disease transmission in the region. Caldwell et al. compared the multiyear dynamics of dengue cases and Ae. aegypti populations from four ecologically varied sites in El Oro Province, Ecuador, and four sites in Kenya (58). They used mechanistic models based on mosquito physiology and found that temperature, rainfall, and humidity predicted both disease and mosquito dynamics relatively well across the diverse site. Anderson et al. retrospectively compared the clinical epidemiology of dengue infections from arbovirus surveillance studies in Machala, Ecuador, and Kamphaeng Phet, Thailand, that used similar cluster-based methods (59). They found that DENV incidence was remarkably alike across both sites; however, they noted a higher occurrence of secondary DENV infections and severe illness in Thailand. They also found a higher number of Ae. aegypti mosquitoes per household and an increasing proportion of subclinical DENV infections with age in Thailand as compared to Ecuador, suggesting a higher force of infection in Thailand.

There has been some initial research on arbovirus phylogenetics and molecular epidemiology in Ecuador. A study of DENV isolates in Ecuador from 2000 to 2007 revealed a relation to strains from the Caribbean region (60). Another study using samples collected in Machala in 2014 and 2015, revealed that the strain of DENV-1 in circulation at the time was likely introduced to Ecuador two separate times, from Colombia and Venezuela and the DENV-2 in circulation came from a single introduction, likely from Colombia or Venezuela (18). This same study found that CHIKV likely originated via two introductions of the virus from the Caribbean or the United States as early as 2011 and 2013, and that the strain present is Ecuador is the Asian strain (61). Earlier studies assessed the molecular epidemiology and rate of viral evolution of DENV-3 in Ecuador, finding higher rates of nucleotide substitution than expected (62) and evidence of relation to strains from Peru (63).

To date there are three reports detailing major dengue outbreaks in coastal Ecuador that occurred in Machala during 2010 (64), Guayaquil during $2012(65,66)$. The 2010 DENV outbreak was the largest dengue outbreak ever documented in the Province of El Oro, Ecuador, caused predominantly by DENV-1. Over 4,000 cases were reported in El Oro, and approximately half of these cases were in the capital city of Machala. During the 2012 outbreak, over 4,000 cases of dengue fever were reported in Guayaquil alone. Both studies found that spatial patterns of dengue incidence were not evenly distributed in either cities during the respective outbreaks. Furthermore, the condition of households was identified as a major risk factor for dengue transmission in all studies. Spatial clustering of dengue is often observed during outbreaks in Ecuador, which motivates research to explain these spatial patterns (64-67). Clustering of Ae. aegypti is common and often related to availability of breeding habitats (43).

Environmental and climate drivers of arboviral illness in Ecuador are a principle focus of research due to the strong seasonal patterns of disease transmission and the impact of the El Nino/Southern Oscillation (ENSO) on regional climate patterns which drive arboviral epidemics. Multiple studies have linked ENSO to dengue cases in Ecuador $(30,68)$, and there is evidence to suggest that ENSO models and seasonal climate forecast models could potentially be used to predict 
dengue seasons in Ecuador (69). In coastal Ecuador, dengue can be transmitted year-round; however, the disease displays strong annual seasonality in many parts of Ecuador, with cases peaking each year from February-April $(44,68)$. Other interannual effects - likely related to climate, serotypes in circulation, or vector control interventions-determine whether there will be a large dengue outbreak each year $(30,64,68)$. Climate and weather factors are extremely important to arboviral disease, as mosquitoes require certain habitats with standing water to breed and transmission is influenced by ambient temperature (70). Increasing minimum temperature and rainfall have repeatedly been shown to be associated with dengue cases in multiple locations in Ecuador $(30,64,68)$ and have been used to forecast dengue epidemics $(69,71,72)$.

Several studies documented the impact of the April 2016 earthquake on arboviral illness (73-77). Comparisons of the area near the earthquake epicenter from before and after the earthquake found a large increase in the number of Zika cases (76). Increases in stress are a potentially linked to this increase (73), but more importantly, the earthquake coincided with a strong ENSO year (75). The earthquake itself created ecological changes (destruction of buildings) that increased mosquito breeding habitats $(74,77)$. These climate conditions, ecological changes, and socioeconomic vulnerability after the earthquake contributed to the severity of the outbreak $(74,75,77)$. The earthquake also caused delays in care-seeking for these patients (76).

Sociological factors have been shown to affect the abundance of Ae. aegypti in Ecuador. Features of the home, water storage practices, and knowledge of vector-borne diseases impact Ae. aegypti populations (44). Unsurprisingly, these factors also impact dengue risk: home conditions and access to piped water were associated with dengue infections in Machala, El Oro, and Galápagos (64,78). Human behavior is also critical to arboviral disease risk: stress may be related to arboviral infections (73), household mosquito control impacts Ae. aegypti presence, movement patterns affect dengue risk (78), health care seeking behavior and perceptions of health care providers, and holidays or weekends determine whether patients are likely to seek care at a clinic for their dengue-related symptoms $(68,79)$. A detailed analysis of community perceptions and knowledge of dengue was conducted in 2011, providing insights into how people live with the risk of dengue in Ecuador (80). Household efforts to control mosquitos can require considerable time and effort (80), in addition to significant economic resources (81). An analysis of household mosquito control expenditures in Machala found that low-income households spent more than $10 \%$ of discretionary income on mosquito control efforts (81), and price was just as important as effectiveness when choosing mosquito control products. The costs of mosquito control, both in terms of time and money, add to the burden that diseases place on communities while also creating additional challenges to the prevention of dengue outbreaks.

Two types of predictions models have been used to understand arboviral disease in Ecuador. One series of studies focuses on the potential for disease forecasting by combining seasonal climate and ENSO forecasts, showing that the prediction of dengue epidemics, months in advance, may be possible for some cities in Ecuador $(69,71,72)$. Another paper focuses on the clinical experience of arboviral disease, showing that machine learning models could potentially be used to predict whether patients suspected of having an arboviral infection should be hospitalized or sent home (82).

\section{Future Challenges}

Despite the advances in our knowledge regarding arboviral disease transmission and risk factors, there are still many opportunities for future research. Detection of emerging arboviruses, investigating dynamics of co-circulating infections, determining the impact of human movement on patterns of disease transmission, and mitigating potential impacts of climate changes are some examples of future challenges that public health professionals in Ecuador will face. Some current knowledge gaps and avenues for future research are outlined in Table 3.

\section{Table 3: Knowledge Gaps, Challenges and Areas of Future Research}

$$
\text { Knowledge Gap/Challenge Future Research }
$$

Presence of new emerging arboviruses in Ecuador Serological surveys, surveillance of mosquito populations

Sylvatic transmission cycles for arboviruses Active surveillance of mosquitoes and potential reservoir species

Introduction of Zika virus in Ecuador

Phylogenetic research of Zika samples

Synchronicity of viral circulation in mosquito and human Longitudinal coordinated human and mosquito populations surveillance

Role of climate and environment in non-endemic regions of Ecological and cohort studies implementing Ecuador environmental and climate measures for nonendemic areas 
Impact of cross-protection between yellow fever vaccination, Cohort studies with detailed serological profiles prior dengue infection, and/or prior Zika infection on future of subjects and serological surveillance risk for arboviral infection

Role of human movement patterns on spread of arboviruses

Cohort studies collecting movement data, ecological research using movement approximations

New interventions or vector control methods

Field studies for potential interventions, modeling/simulation studies to measure potential impact

Arboviral infections pose an ongoing threat to public health in Ecuador. Vector-borne disease systems are complex, requiring expertise from a broad range of scientific disciplines and health-related fields to design effective management strategies. However, a growing body of research continues to provide new information to help guide policy formation and improve mosquito control efforts. Building upon this base of knowledge will not only help us reduce the impact that prevalent diseases have on local communities, but also strengthen resilience against the threat of future emerging pathogens.

\section{Acknowledgments}

Thanks to MSP, INSPI, Hospital Teófilo Dávila, Froilan Heras Heras, Cinthya Cueva Aponts, Tania Ordoñez, Dr. Mercy Silva, and Dr. Efraín Beltrán Ayala for all the long-term knowledge and work in the field of arboviral epidemiology and ecology, in clinical and field practice. SJR, CAL, AMS were all funded by the NSF EEID DEB 1918681.

\section{References}

1. Mayer SV, Tesh RB, Vasilakis N. The emergence of arthropod-borne viral diseases: A global prospective on dengue, chikungunya and zika fevers. Acta Trop. 2017 Feb;166:155-63.

2. Newson LA. Highland-lowland contrasts in the impact of Old World diseases in early colonial Ecuador. Soc Sci Med 1982. 1993 May;36(9):1187-95.

3. Gardner CL, Ryman KD. Yellow Fever: A Reemerging Threat. Clin Lab Med. 2010 Mar;30(1):237-60.

4. Brathwaite Dick O, San Martín JL, Montoya RH, del Diego J, Zambrano B, Dayan GH. The History of Dengue Outbreaks in the Americas. Am J Trop Med Hyg. 2012 Oct 3;87(4):584-93.

5. Dick GW, Kitchen SF, Haddow AJ. Zika virus. Isolations and serological specificity. Trans R Soc Trop Med Hyg. 1952 Sep;46(5):509-20.

6. Halsey ES, Siles C, Guevara C, Vilcarromero S, Jhonston EJ, Ramal C, et al. Mayaro virus infection, Amazon Basin region, Peru, 2010-2013. Emerg Infect Dis. 2013 Nov;19(11):1839-42.

7. Cevallos V, Ponce P, Waggoner JJ, Pinsky BA, Coloma J, Quiroga C, et al. Zika and Chikungunya virus detection in naturally infected Aedes aegypti in Ecuador. Acta Trop. 2018 Jan;177:74-80.

8. Maucourant C, Petitdemange C, Yssel H, Vieillard V. Control of Acute Arboviral Infection by Natural Killer Cells. Viruses. 2019 31;11(2).

9. Ponce P, Morales D, Argoti A, Cevallos VE. First Report of Aedes (Stegomyia) albopictus (Skuse) (Diptera: Culicidae), the Asian Tiger Mosquito, in Ecuador. J Med Entomol. 2018 Jan 10;55(1):248-9.

10. Kamal M, Kenawy MA, Rady MH, Khaled AS, Samy AM. Mapping the global potential distributions of two arboviral vectors Aedes aegypti and Ae. albopictus under changing climate. PloS One. 2018;13(12):e0210122.

11. Silva LA, Dermody TS. Chikungunya virus: epidemiology, replication, disease mechanisms, and prospective intervention strategies. J Clin Invest. 127(3):737-49.

12. Patterson J, Sammon M, Garg M. Dengue, Zika and Chikungunya: Emerging Arboviruses in the New World. West J Emerg Med. 2016 Nov;17(6):671-9.

13. Izurieta RO, Macaluso M, Watts DM, Tesh RB, Guerra B, Cruz LM, et al. Hunting in the Rainforest and Mayaro Virus Infection: An emerging Alphavirus in Ecuador. J Glob Infect Dis. 2011 Oct;3(4):317-23.

14. Plourde AR, Bloch EM. A Literature Review of Zika Virus. Emerg Infect Dis J [Internet]. 2016;22(7). Available from: http://wwwnc.cdc.gov/eid/article/22/7/15-1990

15. Messina JP, Brady OJ, Scott TW, Zou C, Pigott DM, Duda KA, et al. Global spread of dengue virus types: mapping the 70 year history. Trends Microbiol. 2014 Mar;22(3):138-46.

16. Normile D. Safety concerns derail dengue vaccination program. Science. 2017 Dec 22;358(6370):1514-5.

17. Zambrano H, Waggoner JJ, Almeida C, Rivera L, Benjamin JQ, Pinsky BA. Zika Virus and Chikungunya Virus CoInfections: A Series of Three Cases from a Single Center in Ecuador. Am J Trop Med Hyg [Internet]. 2016 Jul 11; Available from: http://www.ncbi.nlm.nih.gov/pubmed/27402518 
18. Stewart-Ibarra AM, Ryan SJ, Kenneson A, King CA, Abbott M, Barbachano-Guerrero A, et al. The Burden of Dengue Fever and Chikungunya in Southern Coastal Ecuador: Epidemiology, Clinical Presentation, and Phylogenetics from the First Two Years of a Prospective Study. Am J Trop Med Hyg. 2018 May;98(5):1444-59.

19. MSP. Enfermedades Transmitidas por Vectores: Ecuador, SE 1-23/2019. Subsistema de Vigilancia SIVE-Alerta; 2019.

20. CDC. Chikungunya Virus: Symptoms \& Treatment [Internet]. 2018. Available from: https://www.cdc.gov/chikungunya/symptoms/index.html

21. CDC. Dengue: Symptoms [Internet]. 2019. Available from: https://www.cdc.gov/dengue/symptoms/index.html

22. Acosta-Ampudia Y, Monsalve DM, Rodríguez Y, Pacheco Y, Anaya J-M, Ramírez-Santana C. Mayaro: an emerging viral threat? Emerg Microbes Infect [Internet]. 2018 Sep 26 [cited 2020 May 26];7. Available from: https://www.ncbi.nlm.nih.gov/pmc/articles/PMC6156602/

23. CDC. Yellow Fever: Symptoms, Diagnosis, \& Treatment [Internet]. 2019. Available from: https://www.cdc.gov/yellowfever/symptoms/index.html

24. Kleinert RD. Yellow fever: integrating current knowledge with technological innovations to identify strategies for controlling a re-emerging virus. Viruses. 2019;11:960.

25. CDC. Zika Virus: Symptoms [Internet]. 2019. Available from: https://www.cdc.gov/zika/symptoms/symptoms.html 26. MSP. Enfermedades Transmitidas por Vectores: Ecuador, SE 1-52/2019. Subsistema de Vigilancia SIVE-Alerta; 2020.

27. MSP. Enfermedades Transmitidas por Vectores: Ecuador, SE 01-14-2020. Subsistema de Vigilancia SIVE-Alerta; 2020.

28. Pinault LL, Hunter FF. Malaria in highlands of Ecuador since 1900. Emerg Infect Dis. 2012 Apr;18(4):615-22.

29. Gubler DJ. Dengue, urbanization and globalization: the unholy trinity of the 21st century. Trop Med Health. 2011;39(Suppl 4):3-11.

30. Stewart-Ibarra AM, Lowe R. Climate and non-climate drivers of dengue epidemics in southern coastal ecuador. Am J Trop Med Hyg. 2013 May;88(5):971-81.

31. Paniz-Mondolfi AE, Villamil-Gómez WE, Rodríguez-Morales AJ. Usutu virus infection in Latin America: A new emerging threat. Travel Med Infect Dis. 2016 Dec;14(6):641-3.

32. PAHO. Outbreak of Venezuelan equine Encephalitis, 1995. Pan American Health Organization; 1995 p. 16(4). (Epidemiological Bulletin).

33. Aguilar PV, Estrada-Franco JG, Navarro-Lopez R, Ferro C, Haddow AD, Weaver SC. Endemic Venezuelan equine encephalitis in the Americas: hidden under the dengue umbrella. Future Virol. 2011;6(6):721-40.

34. Manock SR, Jacobsen KH, de Bravo NB, Russell KL, Negrete M, Olson JG, et al. Etiology of acute undifferentiated febrile illness in the Amazon basin of Ecuador. Am J Trop Med Hyg. 2009 Jul;81(1):146-51.

35. Sakkas H, Bozidis P, Franks A, Papadopoulou C. Oropouche Fever: A Review. Viruses. 2018 04;10(4).

36. Farrell DF, Lupone CD, Kenneson A, Cueva C, Heydari N, Barzallo Aguilera JH, et al. Case Report: An Acute Chikungunya Infection and a Recent Secondary Dengue Infection in a Peripartum Case in Ecuador. Am J Trop Med Hyg. 2018 Mar;98(3):838-40.

37. Forshey BM, Guevara C, Laguna-Torres VA, Cespedes M, Vargas J, Gianella A, et al. Arboviral Etiologies of Acute Febrile Illnesses in Western South America, 2000-2007. Halstead SB, editor. PLoS Negl Trop Dis. 2010 Aug 10;4(8):e787.

38. Linton YM, Pecor JE, Porter CH, Mitchell LB, Garzon-Moreno A, Foley DH, et al. Mosquitoes of eastern Amazonian Ecuador: biodiversity, bionomics and barcodes. Mem Inst Oswaldo Cruz. 2013;108 Suppl 1:100-9.

39. Asigau S, Hartman DA, Higashiguchi JM, Parker PG. The distribution of mosquitoes across an altitudinal gradient in the Galapagos Islands. J Vector Ecol J Soc Vector Ecol. 2017;42(2):243-53.

40. Asigau S, Parker PG. The influence of ecological factors on mosquito abundance and occurrence in Galápagos. J Vector Ecol J Soc Vector Ecol. 2018;43(1):125-37.

41. Lippi CA, Stewart-Ibarra AM, Loor MEFB, Zambrano JED, Lopez NAE, Blackburn JK, et al. Geographic shifts in Aedes aegypti habitat suitability in Ecuador using larval surveillance data and ecological niche modeling: Implications of climate change for public health vector control. PLoS Negl Trop Dis. 2019;13(4):e0007322.

42. Quintero J, Brochero H, Manrique-Saide P, Barrera-Perez M, Basso C, Romero S, et al. Ecological, biological and social dimensions of dengue vector breeding in five urban settings of Latin America: a multi-country study. BMC Infect Dis. 2014;14(38).

43. Schafrick NH, Milbrath MO, Berrocal VJ, Wilson ML, Eisenberg JN. Spatial clustering of Aedes aegypti related to breeding container characteristics in Coastal Ecuador: implications for dengue control. Am J Trop Med Hyg. 2013 Oct;89(4):758-65.

44. Stewart Ibarra AM, Ryan SJ, Beltran E, Mejia R, Silva M, Munoz A. Dengue vector dynamics (Aedes aegypti) influenced by climate and social factors in Ecuador: implications for targeted control. PLoS One. 2013;8(11):e78263.

45. Eastwood G, Goodman SJ, Cunningham AA, Kramer LD. Aedes taeniorhynchus vectorial capacity informs a preemptive assessment of West Nile virus establishment in Galápagos. Sci Rep. 2013;3:1519.

46. Bataille A, Fournié G, Cruz M, Cedeño V, Parker PG, Cunningham AA, et al. Host selection and parasite infection in Aedes taeniorhynchus, endemic disease vector in the Galápagos Islands. Infect Genet Evol J Mol Epidemiol Evol Genet Infect Dis. 2012 Dec;12(8):1831-41. 
47. Bataille A, Cunningham AA, Cruz M, Cedeño V, Goodman SJ. Adaptation, isolation by distance and humanmediated transport determine patterns of gene flow among populations of the disease vector Aedes taeniorhynchus in the Galapagos Islands. Infect Genet Evol J Mol Epidemiol Evol Genet Infect Dis. 2011 Dec;11(8):1996-2003.

48. Bataille A, Horsburgh GJ, Dawson DA, Cunningham AA, Goodman SJ. Microsatellite markers characterized in the mosquito Aedes taeniorhynchus (Diptera, Culicidae), a disease vector and major pest on the American coast and the Galápagos Islands. Infect Genet Evol J Mol Epidemiol Evol Genet Infect Dis. 2009 Sep;9(5):971-5.

49. Bataille A, Cunningham AA, Cedeño V, Cruz M, Eastwood G, Fonseca DM, et al. Evidence for regular ongoing introductions of mosquito disease vectors into the Galapagos Islands. Proc Biol Sci. 2009 Nov 7;276(1674):3769-75.

50. Asigau S, Salah S, Parker PG. Assessing the blood meal hosts of Culex quinquefasciatus and Aedes taeniorhynchus in Isla Santa Cruz, Galápagos. Parasit Vectors. 2019 Dec 16;12(1):584.

51. Naranjo DP, Qualls WA, Jurado H, Perez JC, Xue R-D, Gomez E, et al. Vector control programs in Saint Johns County, Florida and Guayas, Ecuador: successes and barriers to integrated vector management. BMC Public Health. 2014 Jul 2;14:674.

52. Ryan SJ, Mundis SJ, A. Aquirre, Lippi CA, Beltran E, Heras F, et al. Seasonal and geographic variation in insecticide resistance in Aedes aegypti in southern Ecuador. PLoS Negl Trop Dis.

53. Lippi CA, Mao L, Stewart-Ibarra AM, Heydari N, Ayala EB, Burkett-Cadena ND, et al. A network analysis framework to improve the delivery of mosquito abatement services in Machala, Ecuador. Int J Health Geogr [Internet]. 2020 Feb 11 [cited 2020 May 26];19. Available from: https://www.ncbi.nlm.nih.gov/pmc/articles/PMC7014633/

54. Sippy R, Rivera GE, Sanchez V, Heras F, Morejón B, Beltrán E, et al. Ingested insecticide to control Aedes aegypti: developing a novel dried attractive toxic sugar bait device for intra-domiciliary control. Parasit Vectors. 2020 Dec;13(1):78.

55. Finkelstein JL, Colt S, Layden AJ, Krisher JT, Stewart-Ibarra AM, Polhemus M, et al. Micronutrients, Immunological Parameters, and Dengue Virus Infection in Coastal Ecuador: A Nested Case-Control Study in an Infectious Disease Surveillance Program. J Infect Dis. 2020 Jan 1;221(1):91-101.

56. Farovitch L, Sippy R, Beltran-Ayala E, Endy TP, Stewart-Ibarra AM, Leydet BF. Detection of Antibodies to Spotted Fever Group Rickettsiae and Arboviral Coinfections in Febrile Individuals in 2014-2015 in Southern Coastal Ecuador. Am J Trop Med Hyg. 2019 Sep 23;

57. Mita-Mendoza NK, McMahon E, Kenneson A, Barbachano-Guerrero A, Beltran-Ayala E, Cueva C, et al. Chagas Disease in Southern Coastal Ecuador: Coinfections with Arboviruses and a Comparison of Serological Assays for Chagas Disease Diagnosis. Am J Trop Med Hyg. 2018 Dec 5;99(6):1530-3.

58. Caldwell JM, LaBeaud AD, Lambin EF, Stewart Ibarra AM, Ndenga BA, Mutuku FM, et al. Climate explains geographic and temporal variation in mosquito-borne disease dynamics on two continents. preprint. 2020 Jan;

59. Anderson KB, Stewart-Ibarra AM, Buddhari D, Beltran Ayala EF, Sippy RJ, Iamsirithaworn S, et al. Key Findings and Comparisons From Analogous Case-Cluster Studies for Dengue Virus Infection Conducted in Machala, Ecuador, and Kamphaeng Phet, Thailand. Front Public Health. 2020 Feb 12;8:2.

60. Regato M, Recarey R, Moratorio G, de Mora D, Garcia-Aguirre L, Gónzalez M, et al. Phylogenetic analysis of the NS5 gene of dengue viruses isolated in Ecuador. Virus Res. 2008 Mar;132(1-2):197-200.

61. Maljkovic Berry I, Rutvisuttinunt W, Sippy R, Beltran-Ayala E, Figueroa K, Ryan S, et al. The origins of dengue and chikungunya viruses in Ecuador following increased migration from Venezuela and Colombia. BMC Evol Biol. 2020 Dec;20(1):31.

62. Fajardo A, Recarey R, de Mora D, D’ Andrea L, Alvarez M, Regato M, et al. Modeling gene sequence changes over time in type 3 dengue viruses from Ecuador. Virus Res. 2009 Apr;141(1):105-9.

63. Kochel T, Aguilar P, Felices V, Comach G, Cruz C, Alava A, et al. Molecular epidemiology of dengue virus type 3 in Northern South America: 2000-2005. Infect Genet Evol. 2008 Sep;8(5):682-8.

64. Stewart-Ibarra AM, Munoz AG, Ryan SJ, Ayala EB, Borbor-Cordova MJ, Finkelstein JL, et al. Spatiotemporal clustering, climate periodicity, and social-ecological risk factors for dengue during an outbreak in Machala, Ecuador, in 2010. BMC Infect Dis. 2014;14:610.

65. Lippi CA, Stewart-Ibarra AM, Muñoz ÁG, Borbor-Cordova MJ, Mejía R, Rivero K, et al. The Social and Spatial Ecology of Dengue Presence and Burden during an Outbreak in Guayaquil, Ecuador, 2012. Int J Environ Res Public Health. 2018 23;15(4).

66. Jácome G, Vilela P, Yoo C. Social-ecological modelling of the spatial distribution of dengue fever and its temporal dynamics in Guayaquil, Ecuador for climate change adaption. Ecol Inform. 2019 Jan 1;49:1-12.

67. Castillo KC, Körbl B, Stewart A, Gonzalez JF, Ponce F. Application of spatial analysis to the examination of dengue fever in Guayaquil, Ecuador. Procedia Environ Sci. 2011;7:188-93.

68. Sippy R, Herrera D, Gaus D, Gangnon R, Patz J, Osorio J. Seasonal patterns of dengue fever in rural Ecuador: 20092016. PLoS Negl Trop Dis. 2019;

69. Lowe R, Stewart-Ibarra AM, Petrova D, García-Díez M, Borbor-Cordova MJ, Mejía R, et al. Climate services for health: predicting the evolution of the 2016 dengue season in Machala, Ecuador. Lancet Planet Health. 2017;1(4):e14251.

70. Mordecai EA, Caldwell JM, Grossman MK, Lippi CA, Johnson LR, Neira M, et al. Thermal biology of mosquitoborne disease. Ecol Lett. 2019 Oct;22(10):1690-708.

71. Petrova D, Lowe R, Stewart-Ibarra A, Ballester J, Koopman SJ, Rodó X. Sensitivity of large dengue epidemics in 
Ecuador to long-lead predictions of El Niño. Clim Serv. 2019 Aug;15:100096.

72. Petrova D, Rodo X, Sippy R, Ballester J, Mejia R, Beltran-Ayala E, et al. The 2018-2019 weak El Niño: predicting the risk of a dengue outbreak in Machala, Ecuador. Rev Internatl J Clim.

73. Stewart-Ibarra AM, Hargrave A, Diaz A, Kenneson A, Madden D, Romero MM, et al. Psychological Distress and Zika, Dengue and Chikungunya Symptoms Following the 2016 Earthquake in Bahía de Caráquez, Ecuador. Int J Environ Res Public Health [Internet]. 2017 Dec [cited 2020 May 19];14(12). Available from: https://www.ncbi.nlm.nih.gov/pmc/articles/PMC5750934/

74. Pacheco Barzallo D, Pacheco Barzallo A, Narvaez E. The 2016 Earthquake in Ecuador: Zika Outbreak After a Natural Disaster. Health Secur. 2018 Mar 29;16(2):127-34.

75. Sorensen CJ, Borbor-Cordova MJ, Calvello-Hynes E, Diaz A, Lemery J, Stewart-Ibarra AM. Climate variability, vulnerability and natural disasters: A case study of Zika virus in Manabi. Ecuad 2016 Earthq GeoHealth. 2017;1.

76. Vasquez D, Palacio A, Nuñez J, Briones W, Beier JC, Pareja DC, et al. Impact of the 2016 Ecuador Earthquake on Zika Virus Cases. Am J Public Health. 2017 May 18;107(7):1137-42.

77. Reina Ortiz M, Le NK, Sharma V, Hoare I, Quizhpe E, Teran E, et al. Post-earthquake Zika virus surge: Disaster and public health threat amid climatic conduciveness. Sci Rep. 2017 Dec;7(1):15408.

78. Ryan SJ, Lippi CA, Nightingale R, Hamerlinck G, Borbor-Cordova MJ, Cruz B M, et al. Socio-Ecological Factors Associated with Dengue Risk and Aedes aegypti Presence in the Galápagos Islands, Ecuador. Int J Environ Res Public Health. 2019 Feb 26;16(5).

79. Handel AS, Ayala EB, Borbor-Cordova MJ, Fessler AG, Finkelstein JL, Espinoza RXR, et al. Knowledge, attitudes, and practices regarding dengue infection among public sector healthcare providers in Machala, Ecuador. Trop Dis Travel Med Vaccines. 2016;2:8.

80. Stewart Ibarra AM, Luzadis VA, Borbor Cordova MJ, Silva M, Ordoñez T, Beltrán Ayala E, et al. A social-ecological analysis of community perceptions of dengue fever and Aedes aegypti in Machala, Ecuador. BMC Public Health. 2014 Dec;14(1):1135.

81. Heydari N, Larsen D, Neira M, Beltrán Ayala E, Fernandez P, Adrian J, et al. Household Dengue Prevention Interventions, Expenditures, and Barriers to Aedes aegypti Control in Machala, Ecuador. Int J Environ Res Public Health. 2017 Feb 16;14(2):196.

82. Sippy R, Farrell DF, Lichtenstein D, Nightingale R, Harris M, Toth J, et al. Severity Index for Suspected Arbovirus (SISA): machine learning for accurate prediction of hospitalization in subjects suspected of arboviral infection [Internet]. Epidemiology; 2019 May [cited 2020 Jan 12]. Available from: http://biorxiv.org/lookup/doi/10.1101/647206 